\title{
Anti-Bacterial Activities of Selected Traditional Medicinal Plants Against Urinary Tract Infection Causing Microorganisms
}

\author{
Abel kidane ${ }^{1}$, Aron Rezene ${ }^{1}$, Meron Michael ${ }^{1}$, Ogbay G/hannes ${ }^{1}$, Sham G/Michael ${ }^{1}$, Shewit \\ Mehreteab $^{1}$, Eyob Yohannes ${ }^{2}$, Jeevan Jyoti' ${ }^{2}$, Makda Tesfalem ${ }^{2}$, Hagos Andom ${ }^{3}$ \\ 1,2 Asmara College of Health Sciences, Asmara, Eritrea, aronrezene19@gmail.com \\ ${ }^{3}$ TB focal person, MoH, Zoba Maekel, Asmara,Eritre, hagostuum@gmail.com
}

*Corresponding Author: Hagos Andom, TB focal person, MoH, Zoba Maekel, Asmara, Eritrea. hagostuum@gmail.com

\begin{abstract}
:
Background:

Medicinal plants have a powerful and synergistic effect against most microorganisms due to the presence of phytochemicals they contain. The inappropriate use of antibiotics possess a significant increase in antibiotic resistance globally, gives to scientists a signal to search alternative therapeutic drugs from medicinal plants. Therefore, formulating alternative antibiotics extracted from herbal medicines for treating such infectious disease in an effective and comfortable manner is being essential.
\end{abstract}

\section{Methodology:}

Three plant leaves (Chenopodium murale, Malva parviflora and Lannea furticosa) were collected and extracted using standard methods and the yield was obtained. Phytochemical analysis was done to see the presence of phytochemical compounds in the plants selected. The extracted ingredients were then subjected to the standard bacterial strains to determine their antibacterial activity by measuring the zone of inhibition they possess.

\section{Results:}

Leaves of Lannea fruticosa gave the highest yield in all the extracts, (22.6\%), chloroform extract (7.6\%), ethanol-aqueous extracts (19.04\%). This plant also produced a maximum zone of inhibition of $34 \mathrm{~mm}$ and $24 \mathrm{~mm}$ at the highest concentration $(400 \mathrm{mg} / \mathrm{ml})$ in aqueous extract against both P. aeruginosa and S. aureus respectively. Besides, all the plants had all phytochemical constituents.

\section{Conclusion:}

All the selected traditional medicinal plants had a remarkable antibacterial effect due to the presence of phytochemicals they contain which gives them a potency to have a considerable effect against the UTIS causing infectious organisms.

Keywords: Antibacterial activity, Medicinal Plants, Extraction, Phytochemical, AST

\section{INTRODUCTION}

Microorganisms tend to infect human beings very long years ago [1]. Urinary tract infections (UTIs) are among these most common bacterial infections affecting both genders of all ages [2]. Approximately, 150 million urinary tract infections are diagnosed per year worldwide [3]. As this type of infection usually affects the parts of urinary system and is mainly found among the female population due to the anatomical reasons [2], It is the most commonly diagnosed in women aged 1635 with the average incidence of one present in girls aged less than 16 and four present among the age of 20 and above [2,4]. Recent studies also revealed that, the presence of bacteria in urine in high density increases with age from $2 \%$ to $7 \%$ in women of child bearing age to almost $50 \%$ in elderly women [4]. Generally, the disease is among the most common infectious diseases diagnosed by Health workers in economically transitioning countries with high prevalence in females, especially in 
young females as one third of adult women are diagnosed with UTI before 24 years $[5,6]$. It is believed that, there are a number of predisposing factors which have a powerful influence on the cause of UTI, such as sex, urinary catheters, diabetes, and lack of circumcision and prostate problems [7]. Moreover, Persons with metabolic abnormalities and with spinal cord injury are at high most risk for developing urinary tract infection because of chronic use of catheter, and voiding dysfunction [7]. More than $95 \%$ of UTI infections are caused by single bacterial species E. coli which is the most frequently infecting organisms however, many other bacteria also cause UTIs for example, Klebsiella, Pseudomonas, Enterobacter, Proteus, Staphylococcus, Mycoplasma, Chlamydia, Serratia and Neisseria species [8]. To treat this infection, several potent antibiotics were produced and are commercially available, but increasing drug resistance to these antibiotics has made therapy of UTI difficult, as the bacteria have the genetic ability to transmit and acquire resistance to drugs due to selfmutation and other man made phenomena [9]. Currently, essential extracts of certain plants have been shown to have antimicrobial effects, as well as imparting flavour to foods [10]. The synergistic effect of the mixture of phytochemicals plays a crucial role to use plant extracts as an antimicrobial agents [11]. Even today this area holds much more hidden treasure [12]. Nowadays, the misuse of antibiotics and the significant increase of antibiotic resistance is calling for an accelerated search for novel antibacterial therapeutic agents using herbal medicinal plants [13]. Most of anti-microbial drugs are natural products derived from plants [14]. According to World Health Organization (WHO) medicinal plants would be the best source to obtain a variety of drugs [14], which about $80 \%$ of individuals from developed countries also use traditional medicine, which has compounds derived from medicinal plants [14]. Reports from WHO and different pharmacovigiliance centres also showed that the commercially available antibiotics have several adverse effects which include hypersensitivity, depletion of beneficial gut flora, immunosuppression and allergic reactions [14, 15]. The high prevalence of the disease, the living condition of the communities, shortage of supply of clean water and washing practices, the inadequate supply of drugs, the gradual increase of resistant bacteria against the available antibiotics makes the community to rely heavily in using traditional medicinal plants to treat different infections in the community. Considering the above facts, the aim of this study was to investigate and isolate the biologically active compounds of these traditional medicinal plants that have antimicrobial activity against UTIs causing microorganisms.

\section{Methodology}

\subsection{Study Design}

The study was an experimental study designed to investigate the antibacterial activities of selected traditional medicinal plants against UTIs causing microorganisms.

\subsection{Collection and Identification of Selected Plants}

Leaves of three different plants which are used by traditional healers for treating different health problems especially urinary tract infections (UTIs) were collected from different places of Eritrea during the period of study from January to March 2018. The leaves of these plants (Chenopodium murale, Malva parviflora and Lannea furticosa) were obtained from the vicinity of Asmara and remote areas of the country, which are then used for present experimental study. The plants were:

Malva Parviflora, is locally known as Lehtit. It is found in North African countries and is also widely naturalized in Europe. Some of the Common names include cheese weed, cheese weed mallow, Egyptian mallow, small-flowered marshmallow and small flower mallow. Traditionally, it is used in the treatment of some inflammatory disorders. It has antioxidant and antipyretic activity. It can also be used as a poultice on swelling running sores and boils [16].

Chenopodium Murale is locally known as Hamli kubo. It is found in East African countries: Eritrea, Sudan, Ethiopia, and in some southwest and southern Asian countries. It is a medicinal plant and has wide applications in folk medicines as anthelmintic, stomachic, antispasmodic, diaphoretic, emmenagogue, for the pain of amenorrhea as an abortifacient and for the relief of asthma, catarrh and migraine [17].

Lannea Fruticosa is locally known as Dugdugna. It is found in Tropical Africa, Sub-Saharan areas of Niger and Nigeria to northern Sudan, Eritrea, Ethiopia and Uganda. It has antimicrobial activity [18]. 


\subsection{Extraction and Filtration Techniques}

The leaves of the three plants were thoroughly washed with running tap water and shade dried. The dried plant leaves were disintegrated by feeding it into a hammer mill. The objective for powdering the plant material was to rupture its organ, tissue and cell structures so that its medicinal ingredients are exposed to the extraction solvent. Furthermore, size of the leaves was reduced to maximize the surface area, which in turn enhances the mass transfer of active principle from plant material to the solvent. Then 100 grams from each powdered plants were extracted separately with ethanol- aqueous, chloroform and water. It was left out on an electronic shaker for $48 \mathrm{hrs}$ at 100rpm. The extract so obtained was separated out from the marc (exhausted plant material) by allowing it to trickle into a holding tank through the built-in false bottom of the extractor, which is covered with a filter cloth. The marc is retained at the false bottom, and the extract was received in the holding tank. From the holding tank, the extract was further filtered using whatemann filter paper no. 1 to remove fine or colloidal particles from the extract. The filtered extract was then concentrated under vacuum using the rotary evaporator to produce a thick concentrated extract. Finally, the extracts were dried by placing it in the water bath at $40^{\circ} \mathrm{C}$. The final residue was kept in tightly closed clean glass bottles and stored at $4^{\circ} \mathrm{C}$ for further use.

\subsection{Collection of Bacteria and Antimicrobial Bioassay}

Three standard organisms were procured from Microbiology department of the National Health Laboratory in Asmara, Eritrea. These organisms were E.coli (ATCC 25923), S. aureus (ATCC 25922) and P.aeruginosa (ATCC 27853). These standard bacterial strains were maintained in nutrient broth agar prior to sub-culture on Muller Hinton Agar plates $24 \mathrm{hrs}$ to test the antimicrobial susceptibility testing using these extracted ingredients by inoculating the suspensions prepared using $0.5 \mathrm{McF}$ arland standards [8]. Suspensions of the bacterial strains were then inoculated on Muller Hinton agar plates using a sterile swab. The swab was streaked evenly over the surface of the medium to ensure confluent growth. The antimicrobial sensitivity bioassay was performed by using both disc diffusion and agar well diffusion methods. The dried extracts were dissolved in 5\% DMSO to prepare two concentrations of $200 \mathrm{mg} / \mathrm{ml}$ and $400 \mathrm{mg} / \mathrm{ml}$. One hundred $\mu 1$ of both concentrations was introduced into their respective holes using micro pipette. Equal amount of DMSO was used as a negative control and gentamycin $(10 \mu \mathrm{g})$ in case of P. aeruginosa, and chloramphenicol( $(30 \mu \mathrm{g})$ in case of E.coli and S.aureus was used as a positive control. Finally all the plates were incubated at $37^{\circ} \mathrm{C}$ for $24 \mathrm{hrs}$ to observe the zone of inhibition produced by the extract.

\subsection{Phytochemical Analysis}

Phytochemical examinations were carried out for all the extracts as per the standard methods of qualitative analysis. Hence, the analysis for the presence of five phytochemical constituents namely flavonoids, phenols, glycosides, tannins and saponins was performed and the results were obtained.

\subsection{Data Analysis}

All the experiments of antimicrobial susceptibility testing were performed in triplicate. The results were expressed as the mean \pm standard deviation (SD). Data were statistically analyzed by using one way analysis of variance (ANOVA) followed by Tukey's HSD test using SPSS version 20. P-values were calculated and $\mathrm{P}<0.05$ was considered as statistically significant.

\section{RESULTS}

\subsection{Percentage Yield of the Plant Extracts}

Yield was calculated from all the individual leave extracts of the selected plants. One Hundred grams of each plant were extracted in various solvents. The highest yield was observed by aqueous extract of Lannea fruticosa (Table 1).

Table1. Percent yield of crude extract $(w / w)$

\begin{tabular}{|l|l|l|l|}
\hline Plants used & Aqueous & Ethanol-aqueous & Chloroform \\
\hline Chenopodium murale & $20.2 \%(20.2 \mathrm{~g})$ & $17.3 \%(17.3 \mathrm{~g})$ & $6.8 \%(6.8 \mathrm{~g})$ \\
\hline Malva parviflora & $19.5 \%(19.5 \mathrm{~g})$ & $18 \%(18 \mathrm{~g})$ & $5.6 \%(5.6 \mathrm{~g})$ \\
\hline Lannea fruticosa & $22.6 \%(22.6 \mathrm{~g})$ & $19.04 \%(19.04)$ & $7.6 \%(7.6 \mathrm{~g})$ \\
\hline
\end{tabular}


Anti-Bacterial Activities of Selected Traditional Medicinal Plants Against Urinary Tract Infection Causing Microorganisms

\subsection{Antibacterial Activity of Malva Parviflora Extracts Against Utis Causing Microorganisms}

Ethanol and chloroform extracts of Malva parviflora in both (200mg and $400 \mathrm{mg}$ ) concentrations against S.aureus was found to be significant with inhibition zones of $20 \mathrm{~mm}$ and $18 \mathrm{~mm}$ respectively which were greater than the positive control $17 \mathrm{~mm}$. The plant extracted using the Chloroform had also a considerable effect against P.aeruginosa with a prompting result of $17 \mathrm{~mm}$ zone of inhibition at $400 \mathrm{mg} / \mathrm{dl}$ concentration. This plant has showed no activity against E. coli in both concentrations (Table 2).

Table2. Antibacterial activity of Malva parviflora extracts against E.coli, S.aureus and P.aeruginosa

\begin{tabular}{|c|c|c|c|c|c|c|}
\hline \multirow[t]{3}{*}{ Solvent } & \multicolumn{6}{|c|}{ MALVA PARVIFLORA } \\
\hline & \multicolumn{2}{|l|}{ E.COLI } & \multicolumn{2}{|c|}{ S.AUREUS } & \multicolumn{2}{|c|}{ P.AERUGINOSA } \\
\hline & $\begin{array}{l}400 \mathrm{mg} / \mathrm{ml} \\
\mathrm{M} \pm \mathrm{SD}\end{array}$ & $\begin{array}{l}200 \mathrm{mg} / \mathrm{ml} \\
\mathrm{M} \pm \mathrm{SD}\end{array}$ & $\begin{array}{l}400 \mathrm{mg} / \mathrm{ml} \\
\mathrm{M} \pm \mathrm{SD}\end{array}$ & $\begin{array}{l}200 \mathrm{mg} / \mathrm{ml} \\
\mathrm{M} \pm \mathrm{SD}\end{array}$ & $\begin{array}{l}400 \mathrm{mg} / \mathrm{ml} \\
\mathrm{M} \pm \mathrm{SD}\end{array}$ & $\begin{array}{l}200 \mathrm{mg} / \mathrm{ml} \\
\mathrm{M} \pm \mathrm{SD}\end{array}$ \\
\hline Aqueous & $0.00 \pm 0.00$ & $0.00 \pm 0.00$ & $0.00 \pm 0.00$ & $0.00 \pm 0.00$ & $0.00 \pm 0.00$ & $0.00 \pm 0.00$ \\
\hline Ethanol & $0.00 \pm 0.00$ & $0.00 \pm 0.00$ & $20 \pm 1.41$ & $17 \pm 1.41$ & $0.00 \pm 0.00$ & $0.00 \pm 0.00$ \\
\hline $\begin{array}{l}\text { Chlorofor } \\
\mathrm{m}\end{array}$ & $0.00 \pm 0.00$ & $0.00 \pm 0.00$ & $18 \pm 2.82$ & $13 \pm 0.00$ & $17 \pm 1.41$ & $9 \pm 1.41$ \\
\hline $\begin{array}{l}\text { Positive } \\
\text { control }\end{array}$ & $18.5 \pm 0.7$ & $18.5 \pm 0.7$ & $17.5 \pm 0.7$ & $18.5 \pm 0.7$ & $15.5 \pm 0.7$ & $15.5 \pm 0.7$ \\
\hline $\begin{array}{l}\text { Negative } \\
\text { control }\end{array}$ & $0.00 \pm 0.00$ & $0.00 \pm 0.00$ & $0.00 \pm 0.00$ & $0.00 \pm 0.00$ & $0.00 \pm 0.00$ & $0.00 \pm 0.00$ \\
\hline P-value & 0.000 & 0.000 & 0.000 & 0.000 & 0.000 & 0.000 \\
\hline $\begin{array}{l}\text { Post } \\
\text { hoc(Tukey } \\
\text { HSD) }\end{array}$ & $\mathrm{N}=\mathrm{E}=\mathrm{A}=\mathrm{C}<\mathrm{P}$ & $\begin{array}{l}\mathrm{N}=\mathrm{E}=\mathrm{A}=\mathrm{C}< \\
\mathrm{P}\end{array}$ & $\mathrm{N}<\mathrm{A}<\mathrm{E}=\mathrm{C}=\mathrm{P}$ & $\mathrm{N}<\mathrm{A}<\mathrm{E}=\mathrm{C}=\mathrm{P}$ & $\mathrm{N}<\mathrm{E}<\mathrm{A}<\mathrm{C}=\mathrm{P}$ & $\mathrm{N}<\mathrm{E}<\mathrm{A}<\mathrm{E}<\mathrm{P}$ \\
\hline
\end{tabular}

\subsection{Antibacterial Activity of Chenopodium Murale Extracts Against Utis Causing Microorganisms}

The activity of chloroform extract of Chenopodium murale against S. aureus showed significant effect in both concentrations with inhibition zone of $17 \mathrm{~mm}$ at $200 \mathrm{mg} / \mathrm{ml}$ and $19 \mathrm{~mm}$ at $400 \mathrm{mg} / \mathrm{ml}$ concentrations. Ethanol extract of Chenopodium murale showed less effect against P.aeruginosa only at $400 \mathrm{mg} / \mathrm{ml}$ concentration with $16 \mathrm{~mm}$ inhibition zone. The plant did not show statistically significant effect against all the three standard organisms (Table 3).

Table3. Antibacterial activity of Chenopodium murale extracts against E.coli, S.aureus and P.aeruginosa

\begin{tabular}{|c|c|c|c|c|c|c|}
\hline \multirow[t]{3}{*}{ Solvent } & \multicolumn{6}{|c|}{ CHENOPODIUM MURALE } \\
\hline & \multicolumn{2}{|l|}{ E.COLI } & \multicolumn{2}{|l|}{ S.AUREUS } & \multicolumn{2}{|c|}{ P.AERUGINOSA } \\
\hline & $\begin{array}{l}400 \mathrm{mg} / \mathrm{ml} \\
\mathrm{M} \pm \mathrm{SD}\end{array}$ & $\begin{array}{l}200 \mathrm{mg} / \mathrm{ml} \\
\mathrm{M} \pm \mathrm{SD}\end{array}$ & $\begin{array}{l}400 \mathrm{mg} / \mathrm{ml} \\
\mathrm{M} \pm \mathrm{SD}\end{array}$ & $\begin{array}{l}200 \mathrm{mg} / \mathrm{ml} \\
\mathrm{M} \pm \mathrm{SD}\end{array}$ & $\begin{array}{l}400 \mathrm{mg} / \mathrm{ml} \\
\mathrm{M} \pm \mathrm{SD}\end{array}$ & $\begin{array}{l}200 \mathrm{mg} / \mathrm{ml} \\
\mathrm{M} \pm \mathrm{SD}\end{array}$ \\
\hline Aqueous & $0.00 \pm 0.00$ & $0.00 \pm 0.00$ & $0.00 \pm 0.00$ & $0.00 \pm 0.00$ & $0.00 \pm 0.00$ & $0.00 \pm 0.00$ \\
\hline Ethanol & $0.00 \pm 0.00$ & $0.00 \pm 0.00$ & $16 \pm 0.00$ & $15 \pm 1.41$ & $16.5 \pm 0.7$ & $12 \pm 1.41$ \\
\hline Chloroform & $0.00 \pm 0.00$ & $0.00 \pm 0.00$ & $19 \pm 1.41$ & $17 \pm 0.00$ & $10 \pm 0.00$ & $8.5 \pm 0.7$ \\
\hline $\begin{array}{l}\text { Positive } \\
\text { control }\end{array}$ & $18.5 \pm 0.7$ & $18.5 \pm 0.7$ & $18.5 \pm 0.7$ & $17 \pm 0.7$ & $17.5 \pm 0.7$ & $15.5 \pm 0.7$ \\
\hline $\begin{array}{l}\text { Negative } \\
\text { control }\end{array}$ & $0.00 \pm 0.00$ & $0.00 \pm 0.00$ & $0.00 \pm 0.00$ & $0.00 \pm 0.00$ & $0.00 \pm 0.00$ & $0.00 \pm 0.00$ \\
\hline P-value & 0.000 & 0.000 & 0.000 & 0.000 & 0.000 & 0.000 \\
\hline $\begin{array}{l}\text { Post hoc } \\
\text { (Tukey } \\
\text { HSD) }\end{array}$ & $\mathrm{N}=\mathrm{E}=\mathrm{A}=\mathrm{C}<\mathrm{P}$ & $\mathrm{N}=\mathrm{E}=\mathrm{A}=\mathrm{C}<\mathrm{P}$ & $\mathrm{N}<\mathrm{A}<\mathrm{E}=\mathrm{C}=\mathrm{P}$ & $\mathrm{N}<\mathrm{A}<\mathrm{E}<\mathrm{C}=\mathrm{P}$ & $\mathrm{N}<\mathrm{A}<\mathrm{C}<\mathrm{E}=\mathrm{P}$ & $\mathrm{N}<\mathrm{A}<\mathrm{C}<\mathrm{E}<\mathrm{P}$ \\
\hline
\end{tabular}

\subsection{Antibacterial Activity of Lannea Fruticosa Extracts Against Utis Causing Microorganisms}

Aqueous and chloroform extracts of Lannea fruticosa against E.coli showed $18 \mathrm{~mm}$ and $20 \mathrm{~mm}$ inhibition zone at the highest concentration respectively. All the three extracts of the same plant against S.aureus were found to be significant with $24 \mathrm{~mm}, 19 \mathrm{~mm}$ and $21 \mathrm{~mm}$ zone of inhibitions respectively. The maximum result from all extracts was displayed by the aqueous extract of Lannea 
Anti-Bacterial Activities of Selected Traditional Medicinal Plants Against Urinary Tract Infection Causing Microorganisms

fruticosa against $P$. aeruginosa with an inhibition zone of $34 \mathrm{~mm}$ at $400 \mathrm{mg} / \mathrm{ml}$ which is a substantial effect, almost a fold higher than the positive control $17 \mathrm{~mm}$. This medicinal plant showed the only statistically significant activity against E.coli (Table 4).

Table4. Antibacterial activity of Lannea fruticosa extracts against E. coli, S. aureus and P. aeruginosa

\begin{tabular}{|c|c|c|c|c|c|c|}
\hline \multirow[t]{3}{*}{ Solvent } & \multicolumn{6}{|c|}{ LANNEA FRUTICOSA } \\
\hline & \multicolumn{2}{|l|}{ E.COLI } & \multicolumn{2}{|l|}{ S.AUREUS } & \multicolumn{2}{|c|}{ P.AERUGINOSA } \\
\hline & $\begin{array}{l}400 \mathrm{mg} / \mathrm{ml} \\
\mathrm{M} \pm \mathrm{SD}\end{array}$ & $\begin{array}{l}200 \mathrm{mg} / \mathrm{ml} \\
\mathrm{M} \pm \mathrm{SD}\end{array}$ & $\begin{array}{l}400 \mathrm{mg} / \mathrm{ml} \\
\mathrm{M} \pm \mathrm{SD}\end{array}$ & $\begin{array}{l}200 \mathrm{mg} / \mathrm{ml} \\
\mathrm{M} \pm \mathrm{SD}\end{array}$ & $\begin{array}{l}400 \mathrm{mg} / \mathrm{ml} \\
\mathrm{M} \pm \mathrm{SD}\end{array}$ & $\begin{array}{l}200 \mathrm{mg} / \mathrm{ml} \\
\mathrm{M} \pm \mathrm{SD}\end{array}$ \\
\hline Aqueous & $18.0 \pm 0.00$ & $14 \pm 0.00$ & $24 \pm 0.00$ & $22 \pm 1.41$ & $34 \pm 1.41$ & $20 \pm 2.82$ \\
\hline Ethanol & $12.0 \pm 1.4$ & $11 \pm 1.4$ & $19 \pm 1.41$ & $17 \pm 1.41$ & $0.00 \pm 0.00$ & $0.00 \pm 0.00$ \\
\hline Chloroform & $20 \pm 1.4$ & $15 \pm 1.4$ & $21 \pm 1.41$ & $19 \pm 1.41$ & $0.00 \pm 0.00$ & $0.00 \pm 0.00$ \\
\hline $\begin{array}{l}\text { Positive } \\
\text { control }\end{array}$ & $18.5 \pm 0.7$ & $18.5 \pm 0.7$ & $17.5 \pm 0.7$ & $16 \pm 0.7$ & $17.5 \pm 0.7$ & $15.5 \pm 0.7$ \\
\hline $\begin{array}{l}\text { Negative } \\
\text { control }\end{array}$ & $0.00 \pm 0.00$ & $0.00 \pm 0.00$ & $0.00 \pm 0.00$ & $0.00 \pm 0.00$ & $0.00 \pm 0.00$ & $0.00 \pm 0.00$ \\
\hline P-value & 0.000 & 0.000 & 0.000 & 0.000 & 0.000 & 0.000 \\
\hline $\begin{array}{l}\text { Post } \\
\text { hoc(Tukey } \\
\text { HSD) }\end{array}$ & $\mathrm{N}<\mathrm{E}<\mathrm{A}=\mathrm{C}=\mathrm{P}$ & $\mathrm{N}<\mathrm{E}<\mathrm{A}<\mathrm{C}=\mathrm{P}$ & $\mathrm{N}<\mathrm{A}=\mathrm{E}=\mathrm{C}=\mathrm{P}$ & $\mathrm{N}<\mathrm{A}<\mathrm{E}=\mathrm{C}=\mathrm{P}$ & $\mathrm{N}<\mathrm{E}<\mathrm{C}<\mathrm{A}=\mathrm{P}$ & $\mathrm{N}<\mathrm{E}<\mathrm{C}<\mathrm{A}=\mathrm{P}$ \\
\hline
\end{tabular}

\subsection{Phytochemical Analysis}

During the phytochemical analysis, Malva parviflora gave a positive result for all phytochemical constituents whereas Lannea fructicosa was found to have flavonoids, glycosides and tannins. The presence of flavonoids, saponins, and glycosides were also seen in Chenopodium murale. Glycosides were the common phytocompound encountered in all the three plants selected in the study (Table 5).

Table5. Phytochemical analysis

\begin{tabular}{|l|l|l|l|l|l|}
\hline \multirow{2}{*}{ Plants used } & \multicolumn{3}{|c|}{ Phytochemical analysis } \\
\cline { 2 - 7 } & Flavonoids & Saponins & Phenol & Glycosides & Tannin \\
\hline Malva parviflora & + & + & + & + & + \\
\hline Chenopodium murale & + & + & - & + & + \\
\hline Lannea fruticosa & + & - & - & + & \\
\hline
\end{tabular}

(+) Presence

(-)Absence

\section{DISCUSSION}

Medicinal plants play a significant role in supporting the primary health care in most economically transitioning countries like Eritrea. However, very limited attempts have been done to scientifically explore, document and promote the widely used medicinal plants and associated knowledge dynamics in the country. Recently, there has been considerable interest in the use of plant material as an alternative method to control pathogenic microorganisms [19].

In the present study three plant leaves were subjected to cold extraction to prepare different extracts. The percentage yield of all the extracts was calculated separately. Moreover, phytochemical analysis was also done to examine the presence of the phytochemical compounds.

Aqueous extracts of all three plant materials showed highest percentage yield, however chloroform crude extracts were calculated to have the least percentage yield as it can be shown in table -1. Leaves of Lannea fruticosa gave the highest yield in all the extracts, aqueous extract (22.6\%), chloroform extract $(7.6 \%)$, ethanol-aqueous extracts $(19.04 \%)$, followed by Aqueous extracts of Chenopodium murale and Malva parviflora which were $20.2 \%$ and $19.5 \%$ respectively.

The antibacterial activity of these extracts was performed against selected standard bacterial organisms. These organisms E.coli (ATCC 25923), S. aureus (ATCC 25922) and P.aeruginosa (ATCC 27853), were cultured in nutrient broth agar general media. The Suspensions of the bacterial strains prepared using the $0.5 \mathrm{McFarland}$ standards were then sub-cultured and inoculated on Muller Hinton agar plates using a sterile swab and incubated for 24 hours at $37^{\circ} \mathrm{C}$. The antimicrobial 
susceptibility testing was carried out against these standard organisms using the extracted ingredients [8]. Finally all the plates were incubated at $37^{\circ} \mathrm{C}$ for $24 \mathrm{hrs}$ to observe the zone of inhibition produced by the extracts. The extracted leave of Lannea fructicosa resulted in a remarkable inhibition zone against the tested organisms and was also found to have the highest gram yield in addition to its antibacterial activity.

Lannea fruticosa produced a maximum zone of inhibition of $34 \mathrm{~mm}$ and $24 \mathrm{~mm}$ at the highest concentration $(400 \mathrm{mg} / \mathrm{ml})$ in aqueous extract against both $P$. aeruginosa and S.aureus respectively. In addition to this, the highest activity of Lannea fructicosa in aqueous ethanol extract showed an inhibition zone of $19 \mathrm{~mm}$ (at $400 \mathrm{mg} / \mathrm{ml}$ ) against S.aureus and the least activity was seen against E.coli with an inhibition zone of $12 \mathrm{~mm}$ in $400 \mathrm{mg} / \mathrm{ml}$. In a similar study, an aqueous leaf extract of the plant L.indica showed an inhibition zone of $7 \mathrm{~mm}$ and $8 \mathrm{~mm}$ for P.aeruginosa and S. aureus respectively. In comparison to that study, aqueous extraction of Lannea fructicosa showed a 5-6 fold greater than that of the zone inhibition displayed by L. indica aqueous extract [15].

Ethanol and chloroform extracts of Chenopodium murale were found to be significant against $S$. aureus with inhibition zone of $16 \mathrm{~mm}$ and $19 \mathrm{~mm}$ respectively which made this bacterium more susceptible compared to the other bacteria. But in another study E.coli strain was found to be inhibited easily by extracts of Chrysanthemum species unlike the extracts of Chenopodium murale of this study.

Medicinal plants have a great potentiality to produces large number of organic compounds in the form of secondary metabolites. The secondary metabolites of plants classify on the basis of their functions like chemotherapeutic, bacteriostatic and antimicrobial [20]. Our present study revealed good antibacterial effect of plant extracts toward a panel of microorganisms under study. This may be due to the rich diversity of phytochemicals such us flavonoid, Saponins, phenols, tannins present in the plant extracts in higher amounts as well as the type of solvent used to completely extract this bioactive compounds present within the plant. A study conducted by Saima Ali et.al, revealed that flavonoids were found to show anti-microbial effects by forming complexes with different extracellular proteins and the proteins residing in the organism's cell walls [21].

All the selected medicinal plants during the study were tested for the presence of phytochemical constituents such as, phenol, flavonoid, Saponin, glycoside, and tannin. The existence of Alkaloids was not analysed due to reagent constraints. In this study, Malva parviflora showed a positive result for all phytochemical constituents whereas Lannea fructicosa was found to have flavonoids, glycosides and tannins. Eventually, flavonoids are known to have a supported antimicrobial activity [21]. A study conducted by Abdullatif Azabdone, also showed that the fresh leaves and stems of Malva parviflora were found to have phenols, flavonoids, saponins, alkaloids, resins, and tannins which have a similar content of the selected plants in this study [22].

\section{CONCLUSION}

In this present study, all plants revealed a general substantial antibacterial effect with a very remarkable inhibition zone against the standards. Most of the extracts showed a higher activity than the commercially available drugs chloramphenicol. This can be attributed to the fact that the rich diversity of phytochemical constituents such us flavonoid, Saponins, phenols, tannins of these plants makes them to give considerable effect against the UTIs causing microorganisms. Recommendations

We are kindly recommending that: An invitro evaluation of this medicinal plants against drug resistant strains to be conducted, Furthermore, identification of the active molecules, In vivo activities of these medicinal plants and their toxicological studies to be carried out in the near future.

\section{ACKNOWLEDGMENT}

Authors would like to thank to the staffs of Microbiology department, NHL for their technical assistance, Staffs of National drug quality control for their technical and moral support.

\section{REFERENCES}

[1] AshutoshKar (2012) Medicinal chemistry: Newer drugs for newer Diseases: $4^{\text {th }}$ edition: New Age international Publishers 30:864-865.

[2] O. Al-Jiffri, Zahira M.F et. Al. (2011) Urinary Tract Infection with Esherichia coli and Antibacterial Activity of Some Plants Extracts. Intl. J. Microbiol. Res., 2 (1): 01-07, 2011. 
[3] Salvatore, S., Cattoni, E., Siesto, G., Serati, M., Sorice, P. andTorella, M. (2011) European Journal of Obstetrics, Gynecology, and Reproductive Biology,156(2), 131-136

[4] Dielubanza, E. J. and Schaeffer, A. J. (2011) The Medical Clinics of North America, 9(1), $27-41$.

[5] Colgan, R. and Williams, M. (2011) American Family Physician,84(7), 771-776.

[6] Foster, R. T. S. (2008) Obstetrics \& Gynecology Clinicians North American, 35,235-48.

[7] Raynor, M. C. andCarson, C. C. (2011)The Medical Clinics of North America,95(1), 43-54.

[8] J. Dhanalakshmi, S. Selvi.(2013) Antibacterial Activity of Medicinal Plants used against UTI (Urinary Tract Infection) causing Pathogens, Int. J of Research in Sciences, Volume 1, pp. 01-07.

[9] Srinivasan D, Sangeethan Nathan, Suresh T, Lakshmana P and Permalsamy (2001). Antibacterial activity of Neem (AzadirachTA INDICA) and Tamarind (Tamarindus Indica) leaves, Asian Jr. of Microbiol Biotech \& Env. SC. Vol.3, No. (1-2) :2001:67-73.

[10] Burt S. Essential oils.(2004): their antimicrobial properties and potential application in foods-A review. International Journal of Food Microbiology. 94: 223-253.

[11] Pauli A, Amicbase. Essential Oils Supplementary Information. Review Science, 90513 Zirndorf, Further Str. 13.

[12] Farnsworth NR, Akerele O, Bingel AS.(1985) Medicinal plants in therapy, Bulletin of world health organization. 1985;63: 965-981.

[13] Saeed S, Tariq P. (2005).Antibacterial activities of Mentha piperita, Pisum sativum and Momordica charantia. Pakistan Journal of Botany. 2005; 37: 997.

[14] Poonkothai M, Saravanan M. (2008). Antibacterial activity of Aegle marmelos against leaf, bark and fruit extracts. Ancient science of life. 2008; 27:15. Ellof. J.N. (1998). J. Ethanopharmacol. 60 : 1 - 6

[15] Chandra M. (2013) Antimicrobial Activity of Medicinal Plants against Human Pathogenic Bacteria, Int.J of Biotechnology and Bioengineering Research, Vol, 4,7, pp. 653-658

[16] Pippa J.Michael.et.al. (2009). The Biology of Australian weeds, Marva Parviflora, Plant Protection quarterly, Vol24(1),2009.

[17] Vasishita, p.c., (1989). In: Taxonomy of Angiosperms, Ram Chand, India, pp: 648.

[18] Ken Fern. Useful Tropical Plants Database, Tropical.theferns.info.

[19] Rafi khan Pathan, et al.(2012) In vitro Antimicrobial Activity of Citrus aurantifolia and its Phytochemical screening. Asian Pac J Trop Dis. 2012; 2(4): 328-31.

[20] Alanis, A.J. (2005). Resistance to antibiotics:. Arch. Med. Res.; 36(6): 697-705.

[21] Saima Ali et.al (2018). Phytochemical investigation and antimicrobial appraisal of Parrotiopsis jacquemontiana (Decne) Rehder (2018) 18:43.

[22] Abdullatif Azab. (2017) .Malva: food, medicine and chemistry. Eastern Plants Company, Box 868, Arara, Israel 30026 Fax: +972-(0)4-6356168.

Citation: Andom, H.et al., (2019). Anti-Bacterial Activities of Selected Traditional Medicinal Plants Against Urinary Tract Infection Causing Microorganisms. International Journal of Medicinal Plants and Natural Products (IJMPNP), 5(1), pp.16-22. http://dx.doi.org/10.20431/2454-7999.0501003

Copyright: (C) 2019 Authors, This is an open-access article distributed under the terms of the Creative Commons Attribution License, which permits unrestricted use, distribution, and reproduction in any medium, provided the original author and source are credited. 